\title{
Archives on "Stolen" Childhood: Sensitive Files Finally Described and Opened, if Still Existing...
}

\section{CRISTINA BIANCHI, PH.D.}

Archivist of the city of Pully, and AAS representative in the Section of Professional Associations of the International Council on Archives, Archives of the City of Pully, av. du Prieuré 2, CH-1009 Pully, Switzerland e-mail: Cristina.Bianchi@pully.ch

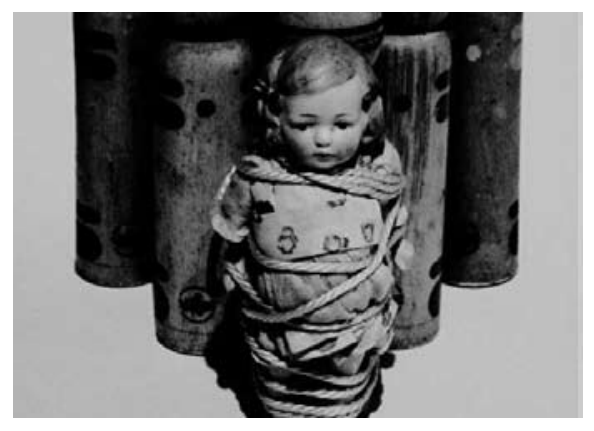

Archives on "Placed" Children: Sensitive files finally opened, if still existing...

Archives on "Stolen" Childhood: Sensitive Files Finally Described and Opened, if Still Existing...

\section{ABSTRACT}

The paper discusses a part of "Swiss dark social history" and its effect on the reorganization of archival fonds, in order to find information about people concerned with coercive measures for assistance. The term "Stolen Childhood" refers to the treatment inflicted by the authorities of Switzerland to children, orphans or from divorced families, forcibly placed in institutions and foster families, which amount to an estimated 100,000 between 1800 and 1980. In relation to this sensitive data, a survey was made about the institutions and repositories which might have kept individual files of these children. Cantonal archives have now centralized this information as much as possible, and described it. Since conservation recommendations and guaranteed access for the people concerned have been issued, special attention is given to records like court orders, divorce papers, which can trace the fate of victims. Other types of traces can be found in municipal archives. On April 12, 2013, Federal Councilor Simonetta Sommaruga officially apologized on behalf of the Swiss Confederation, and asked forgiveness for the suffering inflicted. A measure was passed for distributing financial reparation, as the victims still alive often lead a precarious life.

Key words: data protection, access, legal measures, inventories

Archivi sull'infanzia "rubata": cartelle sensibili finalmente descritte e aperte, se ancora esistenti...

\section{SINTESI}

L'articolo discute una parte dell'" oscuro capitolo della storia sociale svizzera" e il suo effetto sulla riorganizzazione dei fondi archivistici, al fine di trovare informazioni sulle persone che hanno sofferto di misure coercitive a scopo assistenziale. Il termine "infanzia rubata" si riferisce al trattamento inflitto dalle autorità della Svizzera per bambini, orfani o provenienti da famiglie divorziate, forzatamente messi in istituzioni e famiglie affidatarie, che ammontano a circa 100.000 tra il 1800 e il 1980. In relazione a questi dati sensibili, un sondaggio è stato fatto circa le istituzioni e i depositi che potrebbero avere mantenuto le cartelle individuali di questi bambini. Gli archivi cantonali centralizzano e descrivono ora queste informazioni nel miglior modo possibile. Dal momento che le raccomandazioni di conservazione e l'accesso garantito per le persone coinvolte sono stati concessi, particolare attenzione viene data ai record, come ordini del tribunale o documenti per il divorzio, che possono fornire una traccia del destino delle vittime. Altri tipi di tracce possono essere trovati in archivi comunali. Il 12 aprile 2013, la consigliera federale Simonetta Sommaruga si è ufficialmente scusata per conto della Confederazione Svizzera e ha chiesto perdono per le sofferenze inflitte. Una misura è stata approvata per la distribuzione di un risarcimento finanziario, dal momento che le vittime ancora in vita spesso conducono una vita precaria.

Parole chiave: protezione dei dati, accesso, misure legali, inventari 
Arhivsko gradivo o "Ukradenem otroštvu”: Končno popisano in odprto arhivsko gradivo, če še vedno obstaja...

\section{IZVLEČEK}

Članek obravnava del "švicarske temne socialne zgodovine" in njen vpliv na reorganizacijo arhivskih fondov, z namenom, da bi našli informacije o zadevnih, ki se nanašajo na prisilne ukrepe. Izraz "Ukradeno otroštvo" se nanaša na ravnanje švicarskih organov, z otroki, sirotami ali tistimi iz ločenih družin, ki so jih prisilno namestili v institucijah in rejniških družinah. Njigovo število med leti 1800 in 1980 znaša po ocenah 100.000 . V zvezi s temi občutljivimi podatki je bila izvedena raziskava o institucijah, ki bi lahko hranile posamezno gradivo, ki se nanaša na te otroke. Kantonski arhivi so to gradivo sedaj centralizirali, in kolikor je bilo to mogoče, popisali. Ker je bilo izdano priporočilo za ohranitev in zagotovljenje dostopa upravičenim do tega gradiva, je bila posebna pozornost namenjena gradivu kot so na primer sodni nalogi, ločitveni papirji in drugi, na podlagi klaterij je mogoče ugotoviti usodo žrtev. Druge vrste sledi lahko najdemo v občinških arhivih. Dne 12. aprila 2013 se je zvezna poslanka Simonetta Sommaruga uradno opravičil v imenu Švicarske konfederacije, in prosila za odpuščanje za povzročeno trpljenje. Sprejet je bil ukrep o razdelitvi finančnega povračila, saj še vedno žive žrtve, pogosto živijo negotovo življenje.

Ključne besede: varstvo podatkov, dostop, pravni ukrepi, popisi arhivskega gradiva

\section{Introduction}

The term "Stolen Childhood" refers to the treatment inflicted by the authorities of Switzerland to children, orphans or from divorced families, forcibly placed in institutions and foster families (see Heller, Avvanzino and Lacharme, 2005).

An estimated 100,000 is the number of children who were forced to leave their families, between 1800 and 1980. The reasons for these placements, mainly in farming families, but also in religious institutions, were many: poverty, death of parents, divorce, illegitimate birth, without forgetting "moral neglect", i.e. the incompatibility of parents' lifestyle with bourgeois standards of the time.

For the authorities, entrusting children to other families was much less expensive than providing assistance to the parents. Often deprived of love and brutally educated, these children were used as cheap labor or were victims of abuse of all kinds.

For a long time their fate was surrounded by a guilty silence. But from 1990, thanks to the testimony of several of them, this reality emerged. In 2003, the Swiss Parliament passed a credit for a thorough historical research on this topic.

On April 12, 2013, Federal Councilor Simonetta Sommaruga officially apologized on behalf of the Swiss Confederation, and asked forgiveness for the suffering inflicted.

In relation to this sensitive data, what was destroyed, what has been preserved? Since conservation recommendations were issued, the cantonal archivists now pay special attention to this issue. Court orders, divorce papers, can for example trace the fate of the victims of coercive measures and placements outside the family.

News regularly highlight the importance of being able to rely on the most complete nominative files as possible in order to restore stolen or sacrificed life course. Noting that historical research is made of flesh and blood, not just statistics, one of the cantonal archivists sees personal data as an undeniable part of historic preservation, and therefore: "It should not be destroyed in the name of the right to be forgotten."

\section{Sensitive files in the archives}

Australia has its Stolen generation, where mixed-race children of Aboriginal descent were removed from their families by the Australian Federal and State government agencies and church missions, under acts of their respective parliaments (see Discover stories, 2016), as part of the idea of assimilation. Canada has its Stolen generation, where, for nearly a century, the government forced indigenous 
children into residential schools, where up to 75 per cent were neglected and abused (see Annabelle Quince, 2015).

Assimilation was founded on the assumption of black/indigenous inferiority and white superiority, which proposed that Indigenous people should be allowed to "die out" through a process of natural elimination, or, where possible, should be assimilated into the white community.

In Switzerland, it was social status and family context that determined the placement of white children from poor families or from "Travellers" in foster care. This measure has impacted on their lives, and today, most of those who are still alive lead a precarious life. The lack of affection, education and profession, added to psychological trauma, as sexual abuse, sterilization, abortion or forced adoption, has not helped them have a happy life as adults. It is therefore important to give them access to archival records when they request it, part of the path to recover self-esteem by finally knowing what really happened, and receive financial reparation.

Access to the files, inventories and preservation of the archives allowing to document the placement of children in the $20^{\text {th }}$ century are very different from one canton to another in Switzerland. It depends on the law about archives, often recent, and laws on information and protection of personal data. Moreover, private archives are not subject to these laws.

Personal files on placed children are unequally preserved in public and private archives. Bad weather, moves, neglect and lack of interest from employees have ended in the destruction of such records in several places. Municipal archives are unequally preserved, by lack of staff. On the other hand, orphanages, foster homes might have deposited files in public archives, or kept them in their cellars.

Regarding access to public archives, it also depends on each area. Often, personal data can only be consulted a hundred years after the closure of the file, or birth or death of the person. This can compromise the research in the $20^{\text {th }}$ century. However, a written demand of consultation can be sent to public archives, and refusal of the authority must be motivated under, for example, protection of predominant private interest.

The most important fonds of individual files has been created by the Service de protection de la Jeunesse (Office of Youth Protection - SPJ). It is a cantonal office in charge of the placement of children in difficulty. It also checks the institutions for children and foster families. Other organizations, like Justice de Paix (General Tribunal), Tribunal des mineurs (Tribunal for Minors) and Tuteur général (General Curator) have important archives that bring complementary information. Foster and religious institutions (see Praz, Avvanzino and Crettaz, 2016) also have archives, but as they have private statutes, they are not under the obligation to give access to their records.

It is only since 1962 that the Cantonal archives of Vaud have asked the SPJ to keep the nominal files of the children and facilitate the records identification by using a single numbering system allowing an easy consultation. Therefore, not everything has been transferred or retrieved, as different numbering systems and classifications had been used during the $20^{\text {th }}$ century, and disposal of records had already started.

It is therefore difficult for a researcher to document the archives of people from whom he has received testimony. The requirement for anonymity and protection of personal data to third parties make personal records inaccessible, except with the formal agreement of the researcher not to disclose the information to the person and that the person must not ask the researcher; moreover, situations must not be identifiable by anyone.

\section{Legal decisions}

A Round Table has been created to establish the truth about this "dark chapter of Swiss recent history", with the participation of directors of Swiss archives. One of the measures is to facilitate the access of the records to the person concerned. "The condition is, firstly, that the authorities and institutions, partly private, which manage the files know how to handle referrals. Moreover, these institutions and authorities must ensure that no file is destroyed until further notice and that the available 
records are kept in order and made accessible. This last condition is also essential both for victims and for the work of historians. Ultimately, it is also for our society" (see Un chapitre sombre, 2016).

Recommendations have been issued by the Swiss Conference of archival directors to authorities, institutions (Recommandations, 2013a) and people concerned (Recommandations, $2013 \mathrm{~b}$ ), in which they say that people concerned by coercion measures are allowed to access nominal records. They explain how to preserve documents, orient in the jungle of local, regional and federal competences, give indications on how to help or be helped by specialists. Rules are given on how to ask for access and consultation, and see the records in the repository. There is no access deadline for the people concerned, but if a document mentions a third party that needs to be protected, part of it can be redacted. Copies can be received free of charge. A disagreement chapter is also present, as people can find wrong information about themselves; they must then mention it to the archivist and a disagreement mention will be added to the information.

A "Point of contact" (Points de contact pour, 2013) has been created for people directly concerned by these coercion measures before 1981. It proposes to support them through different actions: listen to their overwhelming past if they need to talk about it; counsel and support in the estimation of personal situation and how to go forward; establish a communication with professionals like psychologists to help overcome the past or other authorities and archives.

\section{Can information on placed children be found in municipal archives?}

In 2013, the former children affected by coercive measures for assistance obtained official recognition of their status as victims, recognition that has resulted in several steps: public excuses from Federal Councillor Simonetta Sommaruga, appointment of a delegate for victims of coercion for the purpose of assistance, opening of a website in three languages, organization of a round table, and recommendations of the Conference of directors of Swiss archives.

As access to information and records are at the heart of the recognition process that is taking place, the local committees of archivists decided to sensitize its members and offer them some clues to locate information in connection with such placements.

The placement of children

Placement in homes, farms or institutions affected many children in the cantons. The accountability and tracking was held by a cantonal office whose name has changed during the 20th century: Cantonal Institution for abandoned and unhappy childhood (1890-1920), Child Department (19201939 and 1957-1970), Social welfare Department and public assistance (1940-1956), Youth protection Service (since 1970).

As for local authorities and their administration, they could have maintained contact with the parents of children placed with private institutions as well as welcoming institutions and cantonal services.

Access to information

As it is a difficult, complicated and sensitive matter for the aging people who are now seeking information, the cantonal Mediation Office, in cooperation with the State Chancellery, has been nominated and is now responsible for supporting the persons concerned in their efforts, among others, to identify the authority or institution holding the information sought.

If access to records is largely held through the cantonal archives repositories, the officials of municipal archives are also invited to respond. It is important that local archivists make an effort to locate and preserve the information that can enable them to provide reliable answers to this type of requests.

\section{The location of information}

In a review of the conservation of files of placed children, Genevieve Heller (2005) mentioned the role of the Vaud Cantonal Archives, who in 1980 already took steps to preserve records and information available at the time. In 2005, the ACV created finding aids to facilitate access. 
In terms of municipal archives, the researches made by the archival committees, and supplemented exchanges with Geneviève Heller, led to conclude that the presence of placed children files is unlikely to be found in municipal archives.

However, administrative and legal obligations of the municipality to their residents lead to exchanges and decisions that leave traces. Schooling, relationships with parents of children placed, contact with institutions and households located in the municipality, and registration at the residents office might have information related to the investigations. This list is not exhaustive but it shows the variety of sources from which information could be found: minutes of the Municipality, financial accounts, help for the poor, social welfare records, school board, police reports, general correspondence and archives of private institutions that have been retrieved.

Municipal archivists have not been much contacted until now for such research and it is still difficult to imagine the complementarity between these sources and those kept in cantonal archives. Experience will firstly clarify the contours and also identify the categories of the richest municipal records containing information on children in foster care. Two researches in the municipal archives of Pully and Yverdon-les-Bains helped find information that was missing: minutes of the Municipality, correspondence and a file in the archives of an institution.

\section{Case study}

Thanks to this new law in Switzerland, a woman born in 1942 asked the Mediation Office to find information about why she had been torn from her family and put in a nursery. No information was found in the Cantonal archives. She only knew she was coming from the city of Pully, on the border of the Geneva lake.

The municipal archivist of Pully started looking at all the files that might have had some information, but she had no foster home archives or Justice de Paix files. After long searches in all the files having documents dated 1942, she found the following:

1) Residents' registration office: name of the father, born in 1897 and of the mother, separated from the husband in 1943 and gone back to her mother's house. They had three boys and a girl.

- At the same date of the separation, a sentence says "girl sent to the village of X, Small Families" (supposedly a nursery).

- A handwritten sentence in pencil says, across the form: "the father was put in jail on 10.1.1943 by the police of Pully, for serious threats to family members".

2) Letter of the Municipality to a social service, dated June 10, 1940, on military Relief that the family already receives, and that the wife has left for the village $Y$ where her mother lives.

3) In the minutes of June 2, 1941, the Municipality proposes to give to the father, painter in Pully, the job of painting fences along the local train, in order to help him - this in accordance with the estimate provided. The proposal is admitted.

4) Letter of the Municipality to the Cantonal Commission for assistance from Lausanne, dated December 6, 1941, at the request of the Nestlé Nursery for one of the male children.

5) Letter of the Municipality to the Nestlé Nursery, December 19, 1941, saying they should contact the cantonal Commission for support, the only organism competent in the matter. in Pully.

6) Proof of residence, dated 5 April 1943, concerning another of the boys, born January 6, 1940

The archivist sent a copy of these documents to the Mediation Office (Centre Lavi, 2016), who is in charge of communicating whatever is possible and necessary to the former placed child.

It is always a shock to learn, even when one is 74 years old today, that the father drank, was violent, had no job and received military relief, threatened the family member and spent regularly a couple of days in jail. Learn that the mother fled to her own mother, leaving the children behind (too poor, famished and beaten, surely). Learn that she has three brothers, all placed in different institu- 
tions and with whom she lost contact, not remembering anything as she was two years' old when she was displaced...

The mediators say that it is difficult to track the life of such children (see Frachaux, 2015) ${ }^{1}$. There are always "holes" that can't be filled. The person having suffered from measures of coercion on the purpose of assistance, on the other hand, doesn't often want all the details. "They want to know, but not too much", says a social worker...

The difficulty and the frustration of the archivist are to find a good balance between the right to know, the records they can find, well classified or not, and the lack of information due to administrative mismanagement. They should be able to answer the question: "Which measure has been pronounced against this person concerned, when, by which authority, where has it been executed and by which authority and institution?"

\section{References}

Centre lavi (2016). Retreived on april 2016 from http://www.profa.ch/fr/services/centre-lavi/.

Discover stories (2016). Australians Together. Retreived on 19.4.2016 from http://www.australianstogether. org.au/stories/detail/the-stolen-generations.

Frochaux, P. (2015). Nos chers prot. (2015). Nos chers protégés. Trois générations d'assistés à Genève de 1897 à 1947. Retreived on april 2016 http://enbas.net/index.php?id=pierrette-frochaux.

Geneviève Heller, Pierre Avvanzino, Cécile Lacharme. Enfance sacrifiée: Témoignages d'enfants placés entre 1930 et 1970, 42 Les Cahiers, Lausanne, éésp, 2005.

Praz, A. F., Avvanzino, P. And Crettaz, R. (2016). Enfants placés à l'Institut Marini de Montet: Discriminations, maltraitances et abus sexuels. Retreived on april 2016 from http://www.diocese-lgf.ch/fileadmin/documents/Documents/Marini/MARINI_rapport_recherche_2016.pdf.

Points de contact pour les personnes directement concernées par des mesures coercitives à des fins d'assistance et de placement extrafamilial antérieurs à 1981 (2013). Retreived on april 2016 from http://www.fszm.ch/fr/ points_contact.html.

Recommandations de la Conférence suisse des directeurs d'archives suisses CDA aux autorités et aux institutions (2013a). Retreived on april 2016 from http://www.fszm.ch/pdf/ADK-Empfehlung-Behoerden_fr.pdf.

Recommandations de la Conférence suisse des directeurs d'archives suisses CDA aux personnes concernées (2013b). Retreived on april 2016 from http://www.fszm.ch/pdf/ADK-Empfehlung-Betroffene_fr.pdf.

Quince, Annabelle, Phillips, Keri (2015). Canada's Stolen Generations: the legacy of residential shools. Retreived on 19.4.2016 from http://www.abc.net.au/radionational/programs/rearvision/canada\%E2\%80\%99s-stolen-generations/6598518.

Un chapitre sombre de l'histoire sociale suisse (2016). Retreived on april 2016 from http://www.fszm.ch/ fr/index.html.

\section{SUMMARY}

The term "Stolen Childhood" refers to the treatment inflicted by the authorities of Switzerland to children, orphans or from divorced families, forcibly placed in institutions and foster families. An estimated 100,000 is the number of children who were forced to leave their families, between 1800 and 1980. The reasons for these placements, mainly in farming families, but also in religious institutions, were many: poverty, death of parents, divorce, illegitimate birth, forced adoption, without forgetting "moral neglect", i.e. the incompatibility of parents' lifestyle with bourgeois standards of the time. For the authorities, entrusting children to other families was much less expensive than providing assistance to the parents. Often deprived of love and brutally educated, these children were used as cheap labor or were victims of abuse of all kinds, including sterilization. For a long time their fate was surrounded by a guilty silence. But from 1990, thanks to the testimony of several of them, this reality emerged. In 2003, the Swiss Parliament passed a credit for a thorough historical research on this topic. On April 12, 2013, Federal Councillor Simonetta Sommaruga officially apologized on behalf of the Swiss Confederation, and asked forgiveness for the suffering inflicted. A measure was passed for distributing financial reparation, as the victims still alive often lead a precarious life. In relation to this sensitive data, a survey was

1. A book written by an archivist about the placement of 5 children in her family history in Switzerland. 
Cristina BIANCHI: Archives on "Stolen" Childhood: Sensitive Files Finally Described and Opened, if Still Existing..., 65-71

made about the institutions and repositories which might have kept individual files of these children. Cantonal archives have now centralized this information as much as possible, if it has not disappeared or been destroyed. Since conservation recommendations and guaranteed access for the people concerned have been issued, the cantonal archivists pay special attention to this "dark side of Swiss social history". Court orders, divorce papers, among other records, can trace the fate of the victims of coercive measures or placements outside the family. Other traces of the life of such families can be sometimes found in municipal archives, which complete the information already obtained, or give a new insight of what really happened. A real example is given in the case study, without name as it touches sensitive and private data. News regularly highlight the importance of being able to rely on the most complete nominative files as possible in order to restore stolen or sacrificed life course. Noting that historical research is made of flesh and blood, not just statistics, one of the cantonal archivists sees personal data as an undeniable part of historic preservation, and therefore, "It should not be destroyed in the name of the right to be forgotten."

Tipology: 1.04 Professional Article

Submitting date: 05.02.2016

Acceptance date: 20.02 .2016 
